\title{
PROPRIEDADES QUÍMICAS DE UM CAMBISSOLO HÚMICO SOB PREPARO CONVENCIONAL E SEMEADURA DIRETA APÓS SEIS ANOS DE CULTIVO(1)
}

\author{
J aime Antonio de Almeida(2), Ildegardis Bertol ${ }^{(3)}$, Dirceu Leite ${ }^{(4)}$, Andre J úlio \\ do Amaral ${ }^{(4)} \&$ Wilson Antonio Zoldan J únior ${ }^{(4)}$
}

\begin{abstract}
RESUMO
No sistema de preparo convencional, ocorre o revolvimento do solo, incorporando e distribuindo os resíduos vegetais e fertilizantes na camada revolvida. Na semeadura direta, em que não há o revolvimento do solo, por outro lado, os fertilizantes e corretivos são aplicados na superfície e nela são mantidos os resíduos vegetais, o que facilita a formação de gradientes de concentração de nutrientes e de matéria orgânica na camada superficial do solo. Avaliou-se o efeito desses dois sistemas de manejo na modificação de atributos químicos de um Cambissolo Húmico alumínico léptico, em Lages (SC), em 2001, seis anos após o solo ter tido seu pH corrigido, comparados a um sistema com campo nativo. Os tratamentos de manejo do solo, com quatro repetições, foram: preparo convencional executado com uma aração e duas gradagens em rotação (PCR) e em sucessão de culturas (PCS), semeadura direta em rotação (SDR) e em sucessão de culturas (SDS) e campo nativo (CN). No PCR, foram cultivados feijão/pousio/milho/pousio/soja/pousio e, no PCS, milho/pousio. Na SDR, foram cultivados feijão/aveia/milho/nabo/soja/ervilhaca e, na SDS, milho/ervilhaca. Em abril de 2001, foram avaliados os teores de carbono orgânico, P extraível, $\mathrm{K}, \mathrm{Ca}$, Mg eAl trocável $\left(\mathrm{Al}^{3+}\right)$, hidrogênio mais Al $(\mathrm{H}+\mathbf{A l})$, capacidade de troca de cátions (CTC) e pH em água, nas profundidades de 0-2,5; 2,5-5,0; 5,0-10,0; 10,0-15,0; 15,020,0 e 20,0-30,0 cm. Apesar de as diferenças não terem sido significativas, observou-se tendência à redução dos valores de pH e ligei ro aumento dos teores de H + Al nas camadas mais superficiais da semeadura direta em relação ao preparo convencional. Apesar disso, o incremento significativo dos teores de carbono na semeadura direta naquelas camadas parece ter sido responsável pela ligeira redução dos teores de Al trocável. Não se constataram diferenças nos teores de $\mathrm{Ca}$ e Mg entre os sistemas de manejo do solo, apenas ligeiro
\end{abstract}

\footnotetext{
(1) Trabal ho executado com recursos parciais do CNPq e FINEP. Recebido para publicação em dezembro de 2003 e aprovado em março de 2005.

(2) Professor de Gênese, Morfologia e Classificação de Solos do CAV, Universidade do Estado de Santa Catarina - UDESC. Avenida Luiz de Camões 2090, Caixa Postal 281, CEP 88520-000 Lages (SC). Bolsista do CNPq. E-mail: a2jaa@cav.udesc.br

(3) Professor de Uso e Conservação do Solo do CAV, UDESC. Bolsista do CNPq. E-mail: a2ib@cav.udesc.br

(4) Aluno do Curso de Agronomia do CAV, UDESC. Bolsista de Iniciação Científica CNPq-PIBIC.
} 
incremento do Mg em profundidade na semeadura direta. Nesse sistema,
constatou-se acúmulo de K e P nos primeiros centímetros superficiais do solo.

Termos de indexação: manejo do solo, propriedades químicas, métodos de cultivo, rotação de culturas.

\author{
SUMMARY: CHEMICAL PROPERTIES OF A HUMIC CAMBISOL UNDER \\ CONVENTIONAL TILLAGE AND NO-TILLAGE AFTER SIX \\ YEARS OF CROPPING
}

\begin{abstract}
In the conventional tillagesystem thesoil is mobilized, incorporating and distributing crop residues and fertilizers in the arable layer. In no-tillage systems, however, where no soil mobilization occurs, limeand fertilizers areapplied on the soil surface, which combined with the maintenance of crop residues cover favor the formation of a gradient of nutrient and organic matter concentration in the superficial soil layer. In the present study it was evaluated the effect of these two tillage systems on the chemical attributes of a Humic Cambisol, in Lages County, State of Santa Catarina, Brazil, in 2001, six years after thesoil $\mathrm{pH}$ had been corrected by liming. The data werecompared with those of a soil from a nearby native field. The following soil treatments with four replications were used: conventional tillage with one plowing and two diskings in crop rotation (PCR) and in crop succession (PCS), no-tillage in crop rotation (SDR) and in crop succession (SDS), and a native field (CN). The cropping sequence comprised of bean/ fallow/ corn/ fallow/ soybean/ fall ow was adopted in the PCR, whereas the corn/ fallow sequence was adopted in the PCS system. In SDR the sequence was bean/ oat/ corn/ fodder radish/ soybean/ vetch and, whereas corn/ vetch was cultivated in the SDS. In April 2001, organic carbon, extractable phosphorus, exchangeable potassium, calcium, magnesium and aluminum $\left(\mathrm{Al}^{3+}\right)$, potential acidity $(\mathrm{H}+\mathrm{Al})$, cation exchange capacity (CEC), and $\mathrm{pH}$ in water wereanalyzed at the depths 0 2.5; 2.5-5.0; 5.0-10.0; 10.0-15.0; $15.0-20.0$ and $20.0-30.0 \mathrm{~cm}$. Despite the insignificance of the differences, a tendency to a slight $\mathrm{pH}$ reduction and $\mathrm{H}+\mathrm{Al}$ increase was observed in most superficial layers under no-tillage compared to the conventional tillage system. Significant increases of organic carbon in the no-tillage system seem to be responsi ble for the slight reduction of exchangeable Al in those layers. No differences among the systems were verified for exchangeable calcium and magnesium, but there was a slight increase of magnesium with depth in the soil under no-tillagesystem. In this system, an accumulation of $K$ and $P$ was observed in the top centimeters of the soil.
\end{abstract}

Index terms: soil management, chemical properties, cultivation methods, crops rotation.

\section{NTRODUÇÃO}

No Sul do Brasil, a maioria dos solos são ácidos, com níveis altos de Al trocável e baixos valores de soma e saturação por bases (Ernani \& Almeida, 1986). Portanto, independentemente do sistema de manejo adotado, a calagem desses solos é imprescindível para garantir boas produtividades agrícolas.

Antes da instalação do sistema de semeadura direta, recomenda-se que o cal cário seja incorporado à camada arável dos solos ácidos, mas, após a sua adoção, a reaplicação do calcário é feita sobre a superfície (Anghinoni \& Salet, 2000). Em virtude do alto tamponamento da acidez da mai oria dos sol os argilosos do Planalto de Lages (SC), tem-se constatado maior efeito residual da calagem nesses solos do que em outros menos tamponados, o que também foi verificado em condições climáticas semel hantes (Ci iotta et al ., 2002). Graças à crescente adoção do sistema de semeadura direta nos sol os do Sul do Brasil (Silva \& Paladini, 1997), éimportante a avaliação temporal das propriedades químicas do solo neste sistema de manejo em relação a outros, na medida em que estas poderão variar de acordo com o ambiente, tipo e manejo do solo e histórico do uso.

No sistema de semeadura direta, os nutrientes são normalmente aplicados à superfície, criando mai ores gradientes de concentração com as camadas inferiores do que no cultivo convencional, em que os nutrientes são incorporados à camada arável do solo (Ciotta, 2001). Em relação aoP, por ser um nutriente de baixa mobilidade, tem-se freqüentemente constatado que, na semeadura direta, ocorre maior acúmulo desse el emento nos primeiros centímetros 
superficiais (Eltz et al., 1989; De Maria \& Castro, 1993; Bayer \& Mielniczuk, 1997). O comportamento doK nessesistema demanejo dosolotem sidovariável, na mai oria das vezes, ocorrendo concentração maior do nutriente na superfície (Eltz et al., 1989; I smail et al., 1994; Klepker \& Anghinoni, 1995; Oliveira \& Pavan, 1996), embora, em alguns solos, tenha sido verificada certa uniformidade dos teores desse nutriente em profundidade (Franchini et al., 2000).

Em relação aos parâmetros da acidez do solo, por outrolado, a maioria das pesquisas tem demonstrado acidificação das camadas mais superficiais após a condução dos cultivos em semeadura direta (Blevins et al., 1983; Pottker \& Ben, 1998; Ciotta, 2001), notadamente quando o calcário é previamente incorporado à camada arável sem reaplicação posterior em superfície. Esse comportamento tem sido atribuído ao efeito acídico resultante da nitrificação ocasionada pela adição periódica de adubos amoniacais em superfície nesse sistema (Blevins et al., 1983), pelo amônio proveniente da decomposição dos resíduos orgânicos acumulados em superfície, ou, ainda, pel o aumento da concentração el etrolítica verificado na semeadura direta (Ciotta, 2001). Apesar disso, têm sido constatados valores geralmente mais baixos de Al trocável nestas camadas, em virtude da maior complexação desse el emento pela matéria orgânica (Ciotta et al., 2002).

O comportamento do Ca e do Mg é mais variável nos sistemas de manejo do solo e parece depender também do tipo de solo, seqüência de culturas, clima e diferenças na mobilidade intrínseca de cada elemento no solo. O acúmulo superficial de $\mathrm{Ca}$ e $\mathrm{Mg}$ em solos sob semeadura direta foi observado em vários trabal hos (Pavan et al., 1984; I smail et al., 1994; Oliveira \& Pavan, 1996), embora não tenha sido constatado por outros autores (Klepker \& Anghinoni, 1995; Cassol, 1995).

A semeadura direta, por manter os resíduos das culturas sobre a superfície do solo, geralmente promove incremento paulatino nos níveis de carbono nas camadas mais superficiais desse sistema, particularmente nos solos menos tamponados, incrementando a capacidade de troca de cátions e reduzindo a toxidez de Al para as plantas (Bayer, 1992). N os solos mais tamponados, como os da região doPlanalto deLages, entretanto, espera-se queesses efeitos sejam menores, tendo em vista os níveis mais altos de matéria orgânica naturalmente presentes nesses solos.

O objetivo destetrabal ho foi avaliar as alterações nopH emágua, teor decarbono orgânico, $\mathrm{P}$ extraível, $\mathrm{K}, \mathrm{Ca}, \mathrm{Mg}$ e Al trocáveis, hidrogênio mais Al e capacidade de troca de cátions num Cambissolo Húmicoalumínico cujo $\mathrm{pH}$ foi previamente corrigido, submetido ao preparo convencional e semeadura direta, ambos com rotação e sucessão de culturas por seis anos, comparando-as com os atributos encontrados em um campo nativo.

\section{MATERIAL E MÉTODOS}

O trabalho foi realizado num Cambissolo Húmico alumínico léptico, situado a $27^{\circ} 49^{\prime}$ de latitude sul e $50 \circ 20^{\circ}$ 'de longitude oeste, com 937 m de al titude média, na região do Planalto Sul Catarinense. O solo é derivado da alteração de siltitos da formação Rio do Rasto e localiza-se próximo a um topo de el evação.

No experimento em que foram avaliadas as propriedades químicas do solo, a área já vinha sendo utilizada há cinco anos com pastagem cultivada, composta de gramíneas eleguminosas consorciadas. O solo, que já havia recebido adubação e correção prévia da acidez para elevação do $\mathrm{pH}$ a 6,0, apresentava, no momento da instalação deste experimento (maio de 1995), na média da camada de $0-20 \mathrm{~cm}, \mathrm{pH}$ em água $(1: 1)=5,5, \mathrm{Al}$ trocável = $0,2 \mathrm{cmol}_{\mathrm{C}} \mathrm{kg}^{-1}, \mathrm{Ca}+\mathrm{Mg}$ trocáveis $=10,2 \mathrm{cmol}_{\mathrm{C}} \mathrm{kg}^{-1}$, P extraível $=8,4 \mathrm{mg} \mathrm{dm}^{-3}, \mathrm{~K}_{\text {trocável }}=78 \mathrm{mg} \mathrm{dm}^{-3}$ e $\mathrm{MO}=33 \mathrm{~g} \mathrm{~kg}^{-1}$. Nessa mesma camada, o solo apresentava $421 \mathrm{~g} \mathrm{~kg}^{-1}$ de argila, $437 \mathrm{~g} \mathrm{~kg}^{-1}$ de silte e $142 \mathrm{~g} \mathrm{~kg}^{-1}$ de areia, com densidade de partículas $2,69 \mathrm{~kg} \mathrm{dm}^{-3}$.

As parcelas experimentais dos tratamentos preparo convencional e semeadura direta mediam $6,5 \mathrm{~m}$ de largura por $14,5 \mathrm{~m}$ de comprimento, totalizando $94,3 \mathrm{~m}^{2}$ cada uma. A área de campo nativo media $13 \mathrm{~m}$ de largura por $29 \mathrm{~m}$ de comprimento $\left(377 \mathrm{~m}^{2}\right)$, equivalente às quatro repetições dos demais tratamentos.

Os tratamentos de manejo do solo estudados, distribuídos inteiramente ao acaso, com quatro repetições, foram: o preparo convencional, executado com uma aração e duas gradagens, em rotação de culturas (PCR) e em sucessão (PCS), e a semeadura direta, também em rotação de culturas (SDR) e em sucessão (SDS). No PCR, adotou-se a seqüência feijão/pousio/milho/pousio/soja/pousio e, no PCS, a seqüência milho/pousio. NoPCR ePCS, os resíduos da parte aérea do milho, da soja e do feijão foram removidos da área experimental imediatamente após a col heita, permanecendo as soquei ras do milho e da soja. Na SDR, foram cultivados feijão/aveia/ milho/nabo/soja/ervilhaca e, na SDS, milho/ ervilhaca, cujos resíduos da parteaérea das culturas foram mantidos na área experimental após a col heita, com exceção do feijão. Esses tratamentos foram comparados com o campo nativo (CN), o qual foi pastejado até o início do presente experimento (1995), permanecendo em pousio, com roçadas periódicas desde então.

Durante todo o período experimental (1995-2001), foram aplicados, na semeadura direta, $520 \mathrm{~kg} \mathrm{ha}^{-1}$ de $\mathrm{P}_{2} \mathrm{O}_{5}, 588 \mathrm{~kg} \mathrm{ha}^{-1}$ de $\mathrm{K}_{2} \mathrm{O}$ e $333 \mathrm{~kg} \mathrm{ha}^{-1}$ de $\mathrm{N}$ e, no preparo convencional, $375 \mathrm{~kg} \mathrm{ha}^{-1} \mathrm{de}_{2} \mathrm{O}_{5}, 465 \mathrm{~kg} \mathrm{ha}^{-1}$ de $_{2} 0$ e $252 \mathrm{~kg} \mathrm{ha}^{-1}$ de $\mathrm{N}$, distribuídos nos diferentes cultivos. Na semeadura direta, os fertilizantes foram aplicados, na maioria dos casos, em cobertura na 
superfície do solo (em alguns casos foram incorporados com semeadora "saraquá") e, no preparo convencional, foram incorporados após a aração e antes das gradagens.

$\mathrm{Na}$ ocasião da coleta das amostras de solo, em abril de 2001, cultivava-se milho em todas as parcelas, com exceção do campo nativo. A cultura encontrava-se na fase de grão farináceo, ou seja, no último quarto de seu ciclo. As amostras foram col etadas nas entrelinhas da cultura.

Foram determinados o $\mathrm{pH}$ em água, carbono orgânico, $\mathrm{P}$ extraível, $\mathrm{K}, \mathrm{Ca}$, MgeAl trocáveis $\left(\mathrm{Al}^{3+}\right)$, hidrogênio + $\mathrm{Al}(\mathrm{H}+\mathrm{Al})$ e capacidade de troca de cátions efetiva e a $\mathrm{pH} 7$, nas profundidades de 0 2,$5 ; 2,5-5,0 ; 5,0-10,0 ; 10,0-15,0 ; 15,0-20,0$ e 20,0$30,0 \mathrm{~cm}$, em amostras do solo deformadas.

$\mathrm{O} \mathrm{pH}$ foi determinado potenciometricamente, usando uma relação sol o/solução de 1:1. O carbono orgânico foi obtido por oxidação sulfocrômica em banho de areia, sendo determinado por titulação com sulfato ferroso em presença de ferroin. Cál cio, Mge Al foram extraídos com solução neutra de $\mathrm{KCl} 1 \mathrm{~mol} \mathrm{~L}^{-1}$, sendo os dois primeiros quantificados por espectrometria de plasma e o último por titulometria de neutralização com $\mathrm{NaOH}$, em presença defenolftaleína. Os teores de $\mathrm{H}+\mathrm{Al}$ foram extraídos com solução de acetato de $\mathrm{Ca} 0,5 \mathrm{~mol} \mathrm{~L}^{-1} \mathrm{e}$ determinados por titulometria de neutralização com $\mathrm{NaOH}$, em presença de fenolftaleína. Adotaram-se para tanto os procedimentos indicados por Tedesco et al. (1995). Os val ores de CTC efetiva, CTC a pH 7, Soma de Bases (SB) e Saturação por Bases (V \%) foram obtidos por cál culo, segundo E mbrapa (1997).

Os efeitos dos tratamentos de manejo do sol o sobre os atributos químicos foram testados por meio deanáliseda variância. Analisaram-seseparadamente os efeitos das profundidades em cada tratamento e dos tratamentos em cada profundidade. Quando as variáveis foram estatisticamente diferentes, as médias foram comparadas pelo teste de Duncan a $5 \%$. Na discussão dos resultados, os dados referentes aos tratamentos PCR, PCS, SDR e SDS foram comparados em termos relativos ao $\mathrm{CN}$.

\section{RESULTADOS E DISCUSSÃO}

Após seis anos de cultivo continuado do solo, o $\mathrm{pH}$ em água alcançado nos diversos tratamentos manteve-se próximo a 5,5 (Quadro 1), semel hante, portanto, ao valor determinado após a calagem e antes da instalação do experimento. Não se observaram diferenças significativas nos val ores de $\mathrm{pH}$ entre os tratamentos, para nenhuma das profundidades amostradas, o que é coerente com o fato de que, tanto no preparo convencional como na semeadura direta, o calcário foi previamente incorporado na camada arável do solo. Tais resultados assemelham-se aos obtidos por Muzilli (1983) e Sidiras \& Pavan (1985), em Latossolos Vermel hos e Nitossolos Vermel hos argilosos do Paraná. Observa-se, entretanto, ligeira tendência a um decréscimo do $\mathrm{pH}$ no sistema de semeadura direta em relação ao convencional, na profundidade de $0-2,5 \mathrm{~cm}$, mas, na média das camadas de $0-30 \mathrm{~cm}$, os valores foram ligei ramente mais altos, resultante do aumento do $\mathrm{pH}$ em profundidade nesse sistema. Diversos autores (Moschler et al., 1973; Blevins et al., 1983; Ciotta et al., 2002) também constataram val ores mais baixos de $\mathrm{pH}$ em sistema de semeadura direta nas camadas mais superficiais do solo. Isso tem sido atribuído não só à acidificação provocada pela decomposição de material orgânico deixado na superfície do solo nesse sistema, com provável liberação de ácidos orgânicos (Bayer, 1992), mas

Quadro 1. Valores de pH em água num Cambissolo Húmico alumínico léptico, submetido a diferentes sistemas de preparo e cultivo do solo durante seis anos

\begin{tabular}{clllll}
\hline Profundidade & CN & PCS & PCR & \multicolumn{1}{l}{ SDS } & \multicolumn{1}{c}{ SDR } \\
\hline $\mathrm{cm}$ & & $\mathrm{pH}$ & \\
$0,0-2,5$ & 4,73 & $5,43 \mathrm{Aa}(1)$ & $5,55 \mathrm{Aa}$ & $5,31 \mathrm{Ac}$ & $5,33 \mathrm{Ac}$ \\
$2,5-5,0$ & 4,61 & $5,44 \mathrm{Aa}$ & $5,42 \mathrm{Aa}$ & $5,47 \mathrm{Abc}$ & $5,40 \mathrm{Abc}$ \\
$5,0-10,0$ & 4,60 & $5,44 \mathrm{Aa}$ & $5,50 \mathrm{Aa}$ & $5,67 \mathrm{Aab}$ & $5,54 \mathrm{Aabc}$ \\
$10,0-15,0$ & 4,62 & $5,45 \mathrm{Aa}$ & $5,58 \mathrm{Aa}$ & $5,70 \mathrm{Aab}$ & $5,66 \mathrm{Aab}$ \\
$15,0-20,0$ & 4,61 & $5,46 \mathrm{Aa}$ & $5,46 \mathrm{Aa}$ & $5,78 \mathrm{Aa}$ & $5,69 \mathrm{Aa}$ \\
$20,0-30,0$ & 4,62 & $5,41 \mathrm{Aa}$ & $5,24 \mathrm{Aa}$ & $5,68 \mathrm{Aa}$ & $5,40 \mathrm{Abc}$ \\
Média & 4,63 & 5,44 & 5,46 & 5,60 & 5,50 \\
C.V. (\%) & 1 & 5 & 4 & 2 & 3
\end{tabular}

CN: campo nativo; PCS: preparo convencional sucessão de culturas; PCR: preparo convencional rotação de culturas; SDS: semeadura direta sucessão de culturas; SDR: semeadura direta rotação de culturas.

(1) Valores seguidos pela mesma letra, em cada sistema de preparo e cultivo do solo, não diferem entre si pelo teste de Duncan a 5 \%. 
também ao efeito acidificante decorrente da utilização contínua de adubos nitrogenados solúveis de fontes amoniacais (Blevins et al., 1983; Ciotta et al., 2002).

Na área do campo nativo, os val ores de $\mathrm{pH}$ foram mais baixos, pelofatodea acidez nãoter sido corrigida.

Os teores de Al trocável, bem como a acidez potencial ( $\mathrm{H}+\mathrm{Al}$ ) (Quadro 2), foram mais altos no $\mathrm{CN}$, compatíveis com os baixos valores de $\mathrm{pH}$ (Quadro 1) e com os baixos teores de $\mathrm{Ca}$ e $\mathrm{Mg}$ (Quadro 3) constatados nesse sistema, em que a acidez não foi corrigida, mas não diferiram entre si nos demais sistemas.

Embora as diferenças não tenham sido significativas, foram observados teores mais baixos de $\mathrm{Al}^{3+}$ no sistema de semeadura direta em comparação aos do preparo convencional, tanto nas distintas camadas como na média dos valores. Este comportamento indica o efeito do maior aporte e produção de compostos orgânicos nesse sistema, que podem ter provocado mai or complexação do Al, o que também foi constatado por Ciotta el al. (2002) em um Latossolo Bruno localizado em condições climáticas similares às deste trabalho. J á os teores de $\mathrm{H}+\mathrm{Al}$ foram ligeiramente mais altos na camada de $0-2,5 \mathrm{~cm}$ do sistema de semeadura direta, compatíveis com os valores mais baixos de pH em água antes referidos. A maior acidez potencial na SD pode ser explicada pelo maior teor de carbono orgânico, também verificado nessa camada (Quadro 5). Dessemodo, o carbono orgânico contribuiu para aumentar as fontes de acidez potencial do solo na camada superficial, reduzindoligeiramente o pH, bem como para aumentar compostos orgânicos complexantes, diminuindo o $\mathrm{Al}^{3+}$. Ciotta et al. (2002) obtiveram resultados similares no Latossolo Bruno deGuarapuava (PR), tendo observado, ainda, valores menores de Al em solução na semeadura direta quando comparados aos do preparo convencional. Tais resultados explicam, em parte, os níveis altos de produtividade obtidos na semeadura direta, comparáveis aos do preparo convencional, apesar do ligeiro aumento da acidez ativa na camada superficial do solo do primeiro sistema.

No campo nativo (CN), os teores de $\mathrm{Ca}$ e de $\mathrm{Mg}$ foram bastante inferiores aos obtidos nos demais tratamentos, com decréscimo em profundidade (Quadro 3), pelo fato de tal tratamento não ter sofrido calagem e adubação.

Quadro 2. Teores de alumínio trocável e H + Al num Cambissolo Húmico alumínico léptico, submetido a diferentes sistemas de manejo e cultivo do solo durantes seis anos

\begin{tabular}{|c|c|c|c|c|c|}
\hline Profundidade & $\mathbf{C N}$ & PCS & PCR & SDS & SDR \\
\hline \multirow[t]{2}{*}{$\mathrm{cm}$} & 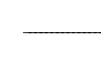 & 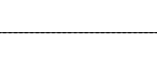 & $\mathrm{cmol}_{\mathrm{c}} \mathrm{kc}$ & & 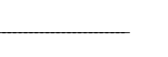 \\
\hline & \multicolumn{5}{|c|}{$\mathrm{Al}^{3+}$} \\
\hline $0,0-2,5$ & 5,0 & $1,3 \mathrm{Ba}^{(1)}$ & $1,0 \mathrm{Bb}$ & $0,8 \mathrm{Ba}$ & $0,6 \mathrm{Ba}$ \\
\hline $2,5-5,0$ & 6,9 & $1,4 \mathrm{Ba}$ & $1,2 \mathrm{Bb}$ & $1,2 \mathrm{Ba}$ & $1,1 \mathrm{Ba}$ \\
\hline $5,0-10,0$ & 7,3 & 1,3 Ba & $0,9 \mathrm{Bb}$ & $0,7 \mathrm{Ba}$ & $0,8 \mathrm{Ba}$ \\
\hline $10,0-15,0$ & 7,6 & $1,3 \mathrm{Ba}$ & $1,0 \mathrm{Bb}$ & $0,7 \mathrm{Ba}$ & $0,6 \mathrm{Ba}$ \\
\hline $15,0-20,0$ & 7,5 & $1,6 \mathrm{Ba}$ & 1,9 Bab & $0,6 \mathrm{Ba}$ & $0,5 \mathrm{Ba}$ \\
\hline $20,0-30,0$ & 7,3 & $2,8 \mathrm{Ba}$ & $3,4 \mathrm{Ba}$ & $1,1 \mathrm{Ba}$ & $2,0 \mathrm{Ba}$ \\
\hline Média & 7,1 & 1,62 & 1,57 & 0,84 & 0,94 \\
\hline \multirow[t]{2}{*}{ C.V. (\%) } & 6 & 59 & 67 & 78 & 106 \\
\hline & & & $\mathrm{H}+\mathrm{Al}$ & & \\
\hline $0,0-2,5$ & 13,71 & $8,72 \mathrm{Ab}$ & $8,72 \mathrm{Aa}$ & $9,94 \mathrm{Aa}$ & $9,30 \mathrm{Aa}$ \\
\hline $2,5-5,0$ & 14,25 & $8,55 \mathrm{Ab}$ & 7,92 Aa & $7,18 \mathrm{Aa}$ & $9,86 \mathrm{Aa}$ \\
\hline $5,0-10,0$ & 14,93 & $8,33 \mathrm{Ab}$ & $8,30 \mathrm{Aa}$ & $8,82 \mathrm{Aa}$ & $8,25 \mathrm{Aab}$ \\
\hline $10,0-15,0$ & 15,16 & $8,81 \mathrm{Ab}$ & 8,72 Aa & 7,88 Aa & 7,74 Aab \\
\hline $15,0-20,0$ & 15,77 & $8,84 \mathrm{Ab}$ & $9,20 \mathrm{Aa}$ & 7,70 Aa & $7,04 \mathrm{Ab}$ \\
\hline $20,0-30,0$ & 14,68 & $12,34 \mathrm{Aa}$ & $10,03 \mathrm{Aa}$ & $8,50 \mathrm{Aa}$ & $7,43 \mathrm{Ab}$ \\
\hline Média & 14,75 & 9,26 & 8,81 & 8,34 & 8,27 \\
\hline C.V. (\%) & 5 & 17 & 13 & 16 & 16 \\
\hline
\end{tabular}

CN : campo nativo; PCS: preparo convencional sucessão de culturas; PCR: preparo convencional rotação de culturas; SDS: semeadura direta sucessão de culturas; SDR: semeadura direta rotação de culturas.

(1) Valores seguidos pela mesma letra, em cada sistema de preparo e cultivo do solo, não diferem entre si pelo teste de Duncan a $5 \%$. 
Quadro 3. Teores de cálcio e magnésio trocáveis num Cambissolo H úmi co alumínico léptico, submeti do a diferentes sistemas de manejo e cultivo do solo durante seis anos

\begin{tabular}{|c|c|c|c|c|c|}
\hline Profundidade & $\mathbf{C N}$ & PCS & PCR & SDS & SDR \\
\hline \multirow[t]{2}{*}{$\mathrm{cm}$} & 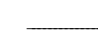 & -2 & $-\mathrm{cmol}_{\mathrm{c} \mathrm{kg}}$ & & {[} \\
\hline & \multicolumn{5}{|c|}{$\mathrm{Ca}^{2+}$} \\
\hline $0,0-2,5$ & 0,7 & $4,8 \mathrm{Aab}^{(1)}$ & 4,8 Aa & 4,7 Aab & 5,6 Aa \\
\hline $2,5-5,0$ & 0,4 & $5,7 \mathrm{Aa}$ & 4,3 Ba & 4,5 ABab & $5,4 \mathrm{Aa}$ \\
\hline $5,0-10,0$ & 0,3 & 4,3 Bab & 4,5 ABa & $4,2 \mathrm{Bb}$ & $5,2 \mathrm{Aa}$ \\
\hline $10,0-15,0$ & 0,2 & 4,1 Bab & 4,5 ABa & 4,6 ABab & $5,5 \mathrm{Aa}$ \\
\hline $15,0-20,0$ & 0,1 & 3,8 Bb & 4,4 ABa & 4,9 ABa & $5,0 \mathrm{Aab}$ \\
\hline $20,0-30,0$ & 0,1 & $3,7 \mathrm{Ab}$ & $3,3 \mathrm{Ab}$ & $4,3 \mathrm{Ab}$ & $3,9 \mathrm{Ab}$ \\
\hline Média & 0,3 & 4,4 & 4,3 & 4,5 & 5,1 \\
\hline \multirow[t]{2}{*}{ C.V. (\%) } & 29 & 24 & 8,0 & 8,0 & 16 \\
\hline & & & $\mathrm{Mg}^{2+}$ & & \\
\hline $0,0-2,5$ & 0,72 & 2,90 Aab & 2,76 Aa & $2,31 \mathrm{Ab}$ & 2,83 $\mathrm{Aa}$ \\
\hline $2,5-5,0$ & 0,44 & $3,27 \mathrm{Aa}$ & $2,49 \mathrm{ABa}$ & $2,25 \mathrm{Bb}$ & $2,73 \mathrm{ABa}$ \\
\hline $5,0-10,0$ & 0,35 & $2,36 \mathrm{Bab}$ & $2,60 \mathrm{ABa}$ & $2,22 \mathrm{Bb}$ & 2,93 Aa \\
\hline $10,0-15,0$ & 0,27 & $2,52 \mathrm{Aab}$ & $2,56 \mathrm{Aa}$ & 2,70 Aa & 3,19 Aa \\
\hline $15,0-20,0$ & 0,21 & $2,06 \mathrm{Bb}$ & 2,58 Aa & 2,84 Aa & 3,27 Aa \\
\hline $20,0-30,0$ & 0,19 & $2,07 \mathrm{Ab}$ & $2,00 \mathrm{Ab}$ & $2,66 \mathrm{Aa}$ & $2,46 \mathrm{Aa}$ \\
\hline Média & 0,36 & 2,53 & 2,49 & 2,50 & 2,90 \\
\hline C.V. (\%) & 19 & 26 & 8,0 & 7,0 & 19 \\
\hline
\end{tabular}

CN : campo nativo; PCS: preparo convencional sucessão de culturas; PCR: preparo convencional rotação de culturas; SDS: semeadura direta sucessão de culturas; SDR: semeadura direta rotação de culturas.

(1) Valores seguidos pela mesma letra, em cada sistema de preparo e cultivo do solo, não diferem entre si pelo teste de Duncan a 5 \%.

Os teores de Ca diferiram entre alguns tratamentos, apenas nas profundidades de 5-10, 1015 e $15-20 \mathrm{~cm}$, sendo significativamente mais baixos no sistema de preparo convencional com sucessão (PCS) em relação aos da semeadura direta com rotação (SDR), o que parece apontar para um efeito positivo da rotação de culturas na semeadura direta em aumentar os teores de Ca neste sistema. E mbora não sejam significativas as diferenças para a mai oria dos tratamentos, constata-se tendência de os valores de Ca e de Mg (Quadro 3) serem mais baixos e os de Al trocável mais altos (Quadro 2) na profundidade de 20-30 cm, em relação às camadas superiores, 0 que deve ser fruto da incorporação do cal cário apenas até à profundidade de $20 \mathrm{~cm}$, em todos os sistemas de preparo.

Os teores de Mg, cujos valores foram muito baixos no campo nativo (CN), não mostraram variações significativas entre os tratamentos de preparo convencional e semeadura direta (Quadro 3). Diferentemente do ocorrido com o $\mathrm{Ca}$, entretanto, houve tendência ao crescimento, embora não significativo, dos teores de $\mathrm{Mg}$ em profundidade no sistema de semeadura direta, principalmente a partir dos $10 \mathrm{~cm}$. Esse comportamento pode estar associado à maior mobilidade desse cátion em relação ao Ca, cuja lixiviação ficou mais bem evidenciada no sistema de semeadura direta pelo fato de o sol o nãoter sido mobilizado durante os seis anos, ao contrário do preparo convencional, onde o solo foi revolvido.

Os valores de CTC a pH 7 e de CTC efetiva não diferiram entre os tratamentos e entre as profundidades, mesmo em relação ao CN (dados não mostrados), sendo os val ores médi os desses atributos, respectivamente, de 16,06 e $8,59 \mathrm{cmol}_{\mathrm{C}} \mathrm{kg}^{-1}$. A ausência de efeitos dos sistemas de manejo, tanto em reduzir a CTC no caso convencional, em que o solo foi mobilizado, quanto em aumentar, no caso da semeadura direta, em que os resíduos foram mantidos na superfície, pode ser atribuída ao alto tamponamento do Cambissolo Húmico de textura argil osa estudado, bem como ao clima úmido e frio dominante na região, que, possivelmente, atenuaram o efeito dos sistemas de manejo do solo sobre esse atributo. A variável tempo de utilização constitui outro fator importante, já que em sol o com características de tamponamento e situado em condi ção climática semel hante à do presente estudo, Ciotta (2001) verificou incremento significativo da CTC a pH 7, após 20 anos de utilização de um Latossolo Bruno em semeadura direta. Em solos 
mais arenosos, com baixo poder tampão, alguns autores (Testa, 1989; Bayer, 1992) também verificaram incrementos significativos na CTC em sistemas de semeadura direta, notadamente nas camadas mais superficiais.

O maior efeito dos sistemas foi constatado para os nutrientes K e P (Quadro 4). Na semeadura direta, os teores deK foram significativamente mais al tos do que os encontrados no preparo convencional, princi pal mente nas amostragens realizadas entre 0 $10 \mathrm{~cm}$, onde os teores foram, pelo menos, o dobro dos observados neste. Essas diferenças deveramse, possivel mente, ao modo de aplicação dos adubos nos dois sistemas. No preparo convencional, eles foram incorporados, antes de cada semeadura, na camada arável do solo, favorecendo a homogeneização do nutriente e, ao mesmo tempo, a sua maior lixiviação daquel a camada. J á na semeadura direta, onde o solo não foi mobilizado, os adubos foram distribuídos a lanço ou incorporados na linha próxima às sementes durante a semeadura, concentrando assim esse nutriente nas camadas mais superficiais do solo.

Em razão da mobilidade do $K$, observou-se claramente a lixiviação desse nutriente, mantendoo acima do nível crítico de $60 \mathrm{mg} \mathrm{kg}^{-1}$ (CFS RS/SC, 1995) até à profundidade de $15 \mathrm{~cm}$, principalmente na SDR, onde os val ores foram mais altos do que na SDS. Essas diferenças também podem ser constatadas, comparando-se a média das camadas de 0-30 cm. Com exceção das camadas de 5-10 e 10-20 cm, nãoseobservaram diferenças significativas nos teores de K trocável entre os sistemas, PCS e PCR, cujos valores, entretanto, foram semel hantes aos do CN esignificativamente mais altos na camada de 0-2,5 cm do queem profundidade (Quadro 4). Tais resultados assemelham-se aos obtidos por Eltz et al . (1989), I smail et al. (1994), K lepker \& Anghinoni (1995) e Oliveira \& Pavan (1996) em condições experimentais similares, mas diferem dos de Franchini et al. (2000) em Latossolo Vermelho distroférrico do Paraná, que não verificaram modificações no teor de K entre os sistemas.

Os valores médios de $P$ extraível na camada de 0-30 cm foram muito baixos no $\mathrm{CN}$ e muito altos nos sistemas de preparo convencional e semeadura direta (Quadro 4). Na semeadura direta, os valores médios foram aproximadamente o dobro dos do preparo convencional. Com exceção da camada de 20-30 cm, verificou-se que os valores de P extraível foram expressivamente menores no $\mathrm{CN}$ do que nos demais sistemas de manejo. Entre os sistemas de manejo, as diferenças ocor reram apenas na camada de $0-2,5 \mathrm{~cm}$, onde os teores de $\mathrm{P}$ foram cerca de

Quadro 4. Teores de potássio e fósforo trocáveis num Cambissolo Húmico al umínico léptico, submetido a diferentes sistemas de manejo e cultivo do solo durante seis anos

\begin{tabular}{|c|c|c|c|c|c|}
\hline Profundidade & CN & PCS & PCR & SDS & SDR \\
\hline \multirow[t]{2}{*}{$\mathrm{cm}$} & . & +2 & $\mathrm{mg} \mathrm{kg}^{-1}$ & & 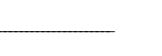 \\
\hline & & & $\mathrm{K}$ & & \\
\hline $0,0-2,5$ & 151 & $104 \mathrm{Ca}^{(1)}$ & $157 \mathrm{Ca}$ & 392 Ba & $466 \mathrm{Aa}$ \\
\hline $2,5-5,0$ & 79 & $64 \mathrm{Bbc}$ & $93 \mathrm{Bb}$ & $266 \mathrm{Ab}$ & $302 \mathrm{Ab}$ \\
\hline $5,0-10,0$ & 55 & $61 \mathrm{Cbc}$ & 87 Bb & $159 \mathrm{Ac}$ & $161 \mathrm{Ac}$ \\
\hline $10,0-15,0$ & 40 & $78 \mathrm{Bb}$ & 77 Bbc & $82 \mathrm{Bd}$ & $141 \mathrm{AC}$ \\
\hline $15,0-20,0$ & 36 & $54 \mathrm{Babc}$ & $60 \mathrm{ABCd}$ & $71 \mathrm{Ad}$ & $51 \mathrm{Abd}$ \\
\hline $20,0-30,0$ & 32 & $43 \mathrm{Cc}$ & $41 \mathrm{Cd}$ & $61 \mathrm{Bd}$ & $80 \mathrm{Ad}$ \\
\hline Média & 65 & 67 & 86 & 172 & 200 \\
\hline \multirow[t]{2}{*}{ C.V. (\%) } & 22 & 23 & 18 & 24 & 11 \\
\hline & & & $\mathrm{P}$ & & \\
\hline $0,0-2,5$ & 2,7 & $17,2 \mathrm{Bb}$ & $13,4 \mathrm{Bbc}$ & $136,0 \mathrm{Aa}$ & $129,1 \mathrm{Aa}$ \\
\hline $2,5-5,0$ & 2,3 & $37,4 \mathrm{Aa}$ & $20,8 \mathrm{ABab}$ & $22,1 \mathrm{ABb}$ & $29,5 \mathrm{Ab}$ \\
\hline $5,0-10,0$ & 3,0 & $16,9 \mathrm{Ab}$ & $22,3 \mathrm{Aa}$ & $20,3 \mathrm{Ab}$ & $13,2 \mathrm{ABbc}$ \\
\hline $10,0-15,0$ & 1,3 & $20,5 \mathrm{Aab}$ & $14,0 \mathrm{Aabc}$ & $11,0 \mathrm{ABb}$ & $13,2 \mathrm{Abc}$ \\
\hline $15,0-20,0$ & 1,1 & $7,8 \mathrm{Ab}$ & $8,4 \mathrm{AC}$ & $7,4 \mathrm{Ab}$ & $8,0 \mathrm{Ac}$ \\
\hline $20,0-30,0$ & 2,1 & $4,7 \mathrm{Ab}$ & $6,2 \mathrm{AC}$ & $5,4 \mathrm{Ab}$ & $5,2 \mathrm{AC}$ \\
\hline Média & 2,1 & 17,4 & 14,2 & 33,7 & 33,0 \\
\hline C.V. (\%) & 41 & 72 & 37 & 65 & 34 \\
\hline
\end{tabular}

CN : campo nativo; PCS: preparo convencional sucessão de culturas; PCR: preparo convencional rotação de culturas; SDS: semeadura direta sucessão de culturas; SDR: semeadura direta rotação de culturas.

(1) Valores seguidos pela mesma letra, em cada sistema de preparo e cultivo do solo, não diferem entre si pelo teste de Duncan a 5 \%. 
Quadro 5. Carbono orgânico num Cambissolo Húmi co alumínico léptico, submeti do a diferentes sistemas de manejo e cultivo do solo durante seis anos

\begin{tabular}{cccccc}
\hline Profundidade & CN & PCS & PCR & SDS & SDR \\
\hline \multicolumn{1}{c}{$\mathrm{cm}$} & \multicolumn{5}{c}{$\mathrm{g} \mathrm{kg}^{-1}$} \\
$0,0-2,5$ & 38,1 & $21,5 \mathrm{Da}(1)$ & $21,6 \mathrm{Da}$ & $32,2 \mathrm{Ca}$ & $35,2 \mathrm{Ba}$ \\
$2,5-5,0$ & 32,0 & $20,4 \mathrm{Ca}$ & $21,1 \mathrm{Ca}$ & $25,5 \mathrm{Bb}$ & $24,1 \mathrm{Bb}$ \\
$5,0-10,0$ & 28,8 & $21,7 \mathrm{Ba}$ & $22,4 \mathrm{Ba}$ & $24,2 \mathrm{Bbc}$ & $22,8 \mathrm{Bcb}$ \\
$10,0-15,0$ & 26,7 & $22,5 \mathrm{Ba}$ & $21,6 \mathrm{Ba}$ & $21,3 \mathrm{Bde}$ & $22,9 \mathrm{Bcb}$ \\
$15,0-20,0$ & 26,1 & $21,0 \mathrm{Ba}$ & $20,6 \mathrm{Ba}$ & $20,4 \mathrm{Be}$ & $21,5 \mathrm{Bcb}$ \\
$20,0-30,0$ & 23,0 & $20,3 \mathrm{ABa}$ & $17,9 \mathrm{Bb}$ & $22,6 \mathrm{Acd}$ & $20,5 \mathrm{Abc}$ \\
Média & 29,1 & 21,2 & 20,9 & 24,5 & 24,5 \\
C.V. (\%) & 6 & 7 & 7 & 6 & 8 \\
\hline
\end{tabular}

CN : campo nativo; PCS: preparo convencional sucessão de culturas; PCR: preparo convencional rotação de culturas; SDS: semeadura direta sucessão de culturas; SDR: semeadura direta rotação de culturas.

(1) Valores seguidos pela mesma letra, em cada sistema de preparo e cultivo do solo, não diferem entre si pelo teste de Duncan a 5 \%.

10 vezes maiores na semeadura direta em relação ao preparo convencional. Altas concentrações de P na camada mais superficial do solo têm sido freqüentemente observadas em sistemas de semeadura direta (Eltz et al., 1989; De Maria \& Castro, 1993; Bayer \& Mielniczuk, 1997), fato atribuído à não-incorporação dos adubos fosfatados, à pequena mobilidade desse nutriente e ao menor contato desses adubos com a fração mineral do solo, que reduzem os processos de adsorção (Muzilli, 1983). Os maiores teores de matéria orgânica em superfície na semeadura direta também podem reduzir a adsorção de $P$, seja pel o bloqueio físico dos sítios de adsorção seja pela competição entre os ânions orgânicos e o P (Martins \& Gonçalves, 1996; Afif et al., 1995).

Em relação ao carbono orgânico (Quadro 5), verificou-se que os valores foram mais el evados no $\mathrm{CN}$, onde a matéria orgânica ficou mais preservada em virtude da não-mobilização do solo, da maior diversidade de espécies vegetais e da provável maior reciclagem do carbono propiciada pela reposição continuada do material orgânico vegetal. As reduções do carbono orgânico no preparo convencional e na semeadura direta, em relação ao campo nativo, foram, em média, respectivamente, de 8 e de $4,5 \mathrm{~g} \mathrm{~kg}^{-1}$, o que denota a influência do sistema de manejo do solo na ciclagem do carbono. Os teores de carbono orgânico foram significativamente mais al tos na semeadura direta apenas nas profundidades de $0-2,5$ e $2,5-5,0 \mathrm{~cm}$, denotando a importância desse sistema no incremento paulatino dos níveis de matéria orgânica do solo nas camadas superficiais, tal como foi observado em outros trabal hos (Bayer \& Miel niczuk, 1995; Bayer \& Bertol, 1999; Ciotta et al., 2002). No preparo convencional, a redução deveu-se à remoção da parte aérea das culturas, tanto na rotação como na sucessão, permanecendo apenas as soqueiras da cultura do milho que foram incorporadas na camada arável, favor ecendo a decomposição mais rápida do material. J á na semeadura direta, tanto as soqueiras como a parte aérea das culturas, com exceção do feijão, permaneceram sobre a superfície do solo, garantindo maior aporte de material orgânico e, ao mesmo tempo, favor ecendo sua decomposição mais lenta (Bayer \& Bertol, 1999), o que explica os maiores teores de C na camada de $0-2,5 \mathrm{~cm}$ nesse sistema, cujos valores mantiveram-se em níveis mais próximos do $\mathrm{CN}$.

\section{CONCLUSÕES}

1. A calagem prévia do solo, realizada em 1995, resultou em aumento do $\mathrm{pH}$ para valores em torno de 5,5 nos tratamentos de preparo convencional e semeadura direta, os quais praticamente não se modificaram após seis anos de cultivo.

2. Na semeadura direta, apenas na camada de $0-2,5 \mathrm{~cm}$, ocorreram ligeiro incremento da acidez potencial edecréscimo do $\mathrm{pH}$, associados à pequena redução dos níveis de Al trocável.

3. Não houve diferenças nos teores de $\mathrm{Ca}^{2+}, \mathrm{Mg}^{2+}$ eCTC entre os sistemas de preparo ecultivo do solo, tendo ocorrido apenas pequeno incremento nos teores de $\mathrm{Mg}^{2+}$ em profundidade na semeadura direta.

4. A semeadura direta aumentou significativamente o teor de carbono orgânico na camada de $0-2,5 \mathrm{~cm}$ eo deP eK na profundidade de $0-10 \mathrm{~cm}$ em relação ao preparo convencional. 


\section{LITERATURA CITADA}

ANGHINONI, I. \& SALET, R.L. Reaplicação do calcário no sistema plantio direto consolidado. In: KAMINSKI, J ., ed. Uso de corretivos da acidez do sol o no plantio direto. Pelotas, Núcleo Regional Sul, Sociedade Brasileira de Ciência do Solo, 2000. (Boletim Técnico, 4)

AFIF, E.; BARRÓN, V. \& TORRENT, J . Organic matter delays but does not prevent phosphate sorption by cerrado soils from Brazil. Soil Sci., 159:207-211, 1995.

BAYER, C. Características químicas do solo, nutrição e rendimento do milho afetados por métodos de preparo e sistemas de culturas. Porto Alegre, Universidade Federal do Rio Grande do Sul, 1992. 172p. (Tese de Mestrado)

BAYER, C. \& BERTOL, I. Características químicas de um Cambissolo húmico afetadas por sistemas de preparo, com ênfasea matéria orgânica. R. Bras.Ci. Solo, 23:687-694, 1999.

BAYER, C. \& MIELNICZUK, J. Características químicas do sol o afetadas por métodos de preparo esistemas de cultura. R. Bras. Ci. Solo, 21:105-112, 1997.

BLEVINS, R.L.; THOMAS, G.W.; SMITH, M.S.; FRYE, W.W. \& CORNELIUS, P.L. Changes in soils properties after 10 years continuous non-tilled and conventionally tilled corn. Soil Till. Res., 3:135-146, 1983.

CASSOL, L.C. Características físicas e químicas do solo e rendimento de culturas após a reaplicação de cal cário, com e sem incorporação, em sistemas de preparo. Porto Alegre, Universidade F ederal do Rio Grande Sul, 1995. 98p. (Tese de Mestrado)

CIOTTA, M.N. Componentes químicos do solo influenciados por sistemas de preparo e modos de calagem em experimento de longa duração. Lages, Universidade do Estado de Santa Catarina, 2001. 102p. (Tese de Mestrado)

CIOTTA, M.N.; BAYER, C.; ERNANI, P.R.; FONTOURA, S.M.V.; ALBUQUERQUE, J.A. \& WOBETO, C. Acidificação de um Latossolo sob plantio direto. R. Bras. Ci. Solo, 26:1055-1064, 2002.

COMISSÃO DE FERTILIDADE DO SOLO - CFS RS/SC. Recomendação de adubação e calagem para os estados do Rio Grande do Sul e Santa Catarina. 3.ed. Passo Fundo, Sociedade Brasileira de Ciência do Solo, 1995. 224p.

DE MARIA, I.C. \& CASTRO, O.M. Fósforo, potássio e matéria orgânica em um Latossolo Roxo sob sistemas de manejo com milho e soja. R. Bras. Ci. Solo, 17:471-477,1993

ELTZ, F.L.F.; PEIXOTO, R.T.G. \& JASTER, F. Efeitos de sistemas de preparo do solo nas propriedades físicas e químicas de um Latossolo Bruno álico. R. Bras. Ci. Solo, 13:259-267, 1989.

EMPRESA BRASILEIRA DE PESQUISA AGROPECUÁRIA EMBRAPA. Manual de métodos de análise do solo. Rio de J aneiro, Serviço Nacional de Levantamento e Conservação do Solo, 1997. 212p.
ERNANI, P.R. \& ALMEIDA, J.A. Avaliação de métodos e recomendação quantitativa de calcário para os solos do estado de Santa Catarina. R. Bras. Ci. Solo, 10:143-150, 1986.

FRANCHINI, J.C.; BORKERT, C.M.; FERREIRA, M.M. \& GAUDÊNCIO, C.A. Alterações na fertilidade do solo em sistemas de rotação de culturas em semeadura direta. $\mathrm{R}$. Bras. Ci. Solo, 24:459-467, 2000.

ISMAIL, I.; BLEVINS, R.L. \& FRYE, W.W. Long term no-tillage on soil properties and continuous corn yields. Soil Sci. Soc. Am. J ., 58:193-198, 1994.

KLEPKER, D. \& ANGHINONI, I. Características físicas e químicas do solo afetadas por métodos de preparo e modos de adubação. R. Bras. Ci. Solo, 19:395-401, 1995.

MARTINS, J.R. \& GONÇALVES, C.N. Estudo de adsorção de fósforo em diferentes profundidades de um solo sob cultivo convencional e plantio direto. In: REUNIÃO SULBRASILEIRA DE CIÊNCIA DO SOLO, Lages, 1996. Resumos expandidos. Lages, Sociedade Brasileira de Ciência do Solo, 1996. p.11-12.

MOSCHLER, W.W.; MARTENS, D.C.; RICH, C.I. \& SHEAR, G.M. Comparative lime effects on continuous no-tillage and conventionally tilled corn. Agron. J ., 65:781-783, 1973.

MUZI LLI, O. Influência do sistema de plantio direto, comparado ao convencional, sobre a fertilidade da camada arável do solo. R. Bras. Ci. Solo, 7:95-102, 1983.

OLIVEIRA, E.L. \& PAVAN, M.A. Control of soil acidity in notillage system for soybean production. Soil Till. Res., 38:4757, 1996.

PAVAN, M.A.; BINGHAM, F.T. \& PRATT, P.F. Redistribution of exchangeable calcium, and magnesium and aluminium foll lowing lime or gypsum applications to a Brazilian Oxisol . Soil Sci. Soc. Am. J ., 48:33-38, 1984.

POTTKER, D. \& BEN, J.R. Calagem para uma rotação de culturas no sistema plantio direto. R. Bras. Ci. Solo, 24:589597, 1998.

SIDIRAS, N. \& PAVAN, M.A. Influência do sistema de manejo do solo no seu nível de fertilidade. R. Bras. Ci. Solo, 9:249254, 1985.

SILVA, J .C.C. \& PALADINI, F.L.S. Extensão rural em plantio direto. In: PEIXOTO, R.T.G.; DIRK, C.A. \& SAMAHA, M.J ., eds. Plantio direto: um caminho para sustentabilidade. Ponta Grossa, 1997. p.43-46.

TEDESCO, M.J .; VOLKWEISS, S.J . \& BOHNEM, H. Análise de solo, plantas e outros materiais. Porto Alegre, Universidade Federal do Rio Grande do Sul, 1985. 188p. (Boletim Técnico, 5)

TESTA, V.M. Características químicas de um Podzólico Vermel ho-Escuro, nutrição e rendimento de mil ho afetados por sistemas de culturas. Porto Alegre, Universidade Federal do Rio Grande do Sul, 1989. 134p. (Tese de Mestrado) 
J aime Antonio de Almeida et al . 